\title{
Improving Understanding Abilities Through Contextual Teaching and Learning in Lesson Study Activities
}

\author{
Ika Meviana*, Nelya Eka Susanti \\ Geographical Education, Faculty of Education \\ Universitas PGRI Kanjuruhan Malang \\ Malang, Indonesia \\ *meviana@unikama.ac.id, nelyaeka@unikama.ac.id
}

\begin{abstract}
Bloom classifies comprehension (Comprehension) into a second cognitive level that describes an understanding, so that students are expected to be able to understand geological material if they can use some relevant rules. In understanding not only understanding an information but also the objectivity, attitude and meaning contained in an information. The purpose of this study was to improve students' understanding of basic geology courses through Contextual Teaching Learning in lesson study activities. The stages of the research carried out were: (1) the planning stage (plan), (2) the implementation stage (do), and (3) the reflection stage (see). Based on the results of Lesson Study activities, it was found that the lesson study activities carried out on an ongoing basis can build learning communities and interactions between lecturers, between students, and between students and lecturers. With this interaction, it can make it easier for students to understand the material.
\end{abstract}

Keywords-CTL, understanding, lesson study, basic geology

\section{INTRODUCTION}

Understanding is the ability to explain and interpret things, be able to provide a broader picture, and explanation and be able to provide more creative descriptions and explanations [1]. Bloom classifies comprehension into a second cognitive level that describes an understanding, so students are expected to be able to understand geological matter if they can use some relevant rules. In understanding not only understanding an information but also the objectify, attitude and meaning contained of an information.

Understanding is one of the important skills that students must have. Understanding is a process of obtaining one's indepth knowledge of information on an object through experience [2]. Increased understanding can be done by inviting children to learn from problems that are close to their daily environment. In learning students must play an active role, seek more, obtain, combine the information obtained so that students can construct their own concepts that they have learned.
Lesson Study is one of the efforts to improve the process and results of learning through collaborative study by a group of teachers/lecturers and is sustainable based on the principles of colleagues and mutual learning to build a learning community [3]. lesson study's main objectives are: (1) gain a better understanding of how students learn and teachers teach; (2) obtain certain results that can be utilized by other teachers, beyond lesson study participants; (3) improve systematic learning through collaborative induction. (4) build a pedagogical knowledge, where a teacher can draw knowledge from another teacher.

Lesson Study is a program of improving the quality of learning implemented by lecturers collaboratively, with the main steps of designing learning to achieve goals, carrying out learning, observing the implementation of the learning, and conducting reflections to discuss the learning that is reviewed as an improvement material in the next learning plan. The main focus of lesson study is student activity in the classroom.

The innovation lesson study will be developed with the Innovation Contextual Teaching Learning (CTL) strategy based on flipped class. Contextual Teaching Learning (CTL) is a learning that encourages students to be able to capture the relationship between the material they learn and real life [4]. This flipped class-based CTL learning begins with the lecturer giving the assignment to students to actively learn in advance the material that will be conveyed through digital media in the form of video or e-book along with some instruction assignments/training questions, as discussion material when learning in the classroom. So that the learning process in the classroom is more focused on the problems of students in understanding the material.

Contextual collaborative method is a method of combining two methods or modification of the collaborative and contextual method. Collaborative method prioritizes learning that involves several students joined together in groups who have different abilities and thoughts for each individual. Combined with contextual learning, the presented materials are 
suitable for the student environment. So that students are able to understand and develop knowledge of the material.

Through this lesson study activity, the weaknesses of model lecturers at every stage of learning implemented can be improved and refined. Based on the analysis of learning quality improvement activities that have been implemented in the Geography Education Program, the plan of understanding improvement program through lesson study to be carried out includes: (1) Workshop lesson study (CTL based flipped class) for lecturers, developing Chapter design and Lesson Design, (2) open lesson for 15 courses, (3) Documenting and publishing Lesson Study, (4) mentoring open lesson (with reflection) at least four times for each course , (5) Carry out monitoring and evaluation of lesson study implementation (6) Seminars and Workshops on implementation, and (7) article writing based on the findings of the effectiveness of the design and learning model developed. The purpose of this research is to improve students' understanding of basic geology courses through Contextual Teaching Learning in lesson study activities.

\section{METHODS}

The strategy used in this lesson study is collaborative learning that provides opportunities for lecturers and students to create a democratic learning environment. The responsibility of lecturers is to motivate students to learn collaboratively in learning, in addition lecturers and students jointly solve problems in collaborative groups. Through peer interaction, theoretically the application of collaborative learning through lesson study in this course is functioned as a laboratory for students in accordance with the expected goals and competencies.

In general, lesson study activities have three steps: (1) plan, (2) do, and (3) see. In the plan step, lecturers plan learning and discuss with observers. At the doo stage, one of the observers is tasked with recording the data using the camera, the shooting is done thoroughly, then editing on some events that are considered important, while the other observer sits in the back. And at the see stage, the whole process of reflection is done to learn valuable lessons that can be obtained.

\section{RESULTS AND DISCUSSIONS}

The application of contextual teaching and learning in lesson study can improve student understanding. This increase is supported by good implementation and planning. The implementation of learning in pre-cycle is less capable of increasing student understanding, because learning is still centred on the lecturer. Meanwhile, the implementation of learning using a contextual teaching and learning approach through lesson study emphasizes learning that is carried out by providing meaningful experiences to students, so that learning is more student-centred.

Students understanding ability through contextual teaching and learning in lesson study activities has increased in each cycle. The increase in understanding ability is presented in the following table.

TABLE I. IMPROVEMENT OF THE AVERAGE ABILITY OF STUDENT UNDERSTANDING

\begin{tabular}{|l|l|l|l|}
\hline & \multicolumn{1}{|c|}{ Average } & \multicolumn{1}{|c|}{ Exhaustiveness } & \multicolumn{1}{c|}{ Criteria } \\
\hline Cycle I & 80.75 & $75 \%$ & Enough \\
\hline Cycle II & 88.45 & $86 \%$ & Good \\
\hline
\end{tabular}

Based on table 1, it is known that the understanding ability of students has increased from cycle 1 to cycle II. This shows that the contextual teaching and learning approach through lesson study has been applied effectively in learning.

Lesson study is a learning practice activity from a number of lecturers and learning experts that can be carried out in three stages of the activity, namely: 1) Plan, 2) Do, and 3) See on the planning and implementation of the learning, in order to improve the quality of learning [5].

These stages have been in accordance the stages of a lesson study that has been proposed [6]. In which they mentioned three stages namely Plan (planning the open class), Do (implementing the open class), and See (reflecting on the open class implementation). The three stages have also been in accordance with the definition that has been proposed by Masaaki [7] in which he defines that lesson plan is an overall sequence of designing lesson plans, performing open class (learning activities), holding a forum of reflection (afterlearning discussion), and archiving the notes on the learning activities.

In the planning activities, identification of problems in the classroom will be used for lesson study activities and alternative planning of solving them. At the implementation stage (do) a lecturer who has been appointed by his group implements a learning implementation plan (RPP) in the classroom. At the reflection stage (see), lecturers who implement the learning implementation plan are given the opportunity to express their impressions during the implementation of the study, both on him and against the student.

Based on the results of the lesson study, the objectives that want to be achieved from learning improvement activities through contextual teaching learning for learning community in lesson study activities in basic geology courses are generally achieved. With the implementation of lesson study activities in developing learning/lectures can improve the ability to understand students and the skills of lecturers on the concept and principles of the implementation of lesson study. This is evidenced by the improvement of the achievability of the learning plan each cycle from the planning results that have been discussed and planned jointly by the lesson study team.

The implementation of lesson study can build a community of learning and interaction between lecturers, between students, and between students and lecturers. With the activity of lesson study will build interaction between lecturers. This is seen 
during the plan or planning stage. At this stage, fellow lecturers in the lesson study team jointly formulate and discuss learning plans that will be implemented in each cycle of lesson study activities. This of course can build and increase interaction between lecturers.

In addition to increasing interaction between lecturers, lesson study activities can also increase interaction between students. In lesson study activities, students are required to be active in group work. In group work activities, students discuss each other to convey their respective opinions. With group work, it can increase interaction between students. But the lecturer has an important role and major in learning. Lofland et al [8] states lecturers is one of the dominant factors that influence the learning process indirectly. Lecturers education and preparation are considered as the main key of educational quality. Due to these reasons, the efforts to improve the lecturer's quality through the programs of lecturer's professionalism and development should be implemented.

Lesson study activities can also build and increase interaction between students and lecturers. When students discuss the assignments on the student activity sheet, students can see the interaction between students and lecturers. Students in groups who do not understand the assignment or steps in the LKM ask the lecturer. In this activity, the lecturer acts as a facilitator in learning. In addition, at the end of the learning activity, lecturers and students conduct questions and answers and collectively make material conclusions at the meeting. However, based on the results of observer observations in cycles 2 and 3 the interaction between students and lecturers has not been seen optimally. This is evidenced by the lack of concern of the model lecturers towards students who are less active. However, in the next cycle the model lecturer has fixed the deficiencies in the form of a lack of concern for less active students. Model lecturers have tried and built interactions by asking students or groups which learning steps or material have not been understood. This of course can increase the interaction between students and lecturers.

Based on the results and discussion, it can be concluded that the implementation of lesson study can increase the professionalism of lecturers. The implementation of lesson study on an ongoing basis is believed to be able to improve daily learning practices. Improving learning practices will lead to improving the quality of the process and student learning outcomes.

The application of lesson study is the right way for lecturers to develop themselves. In addition, it can also be a room to improve professionalism as an educator. This is in accordance with the opinion of the [9], this way is effective for improving the teacher's professional capacities and the teacher's authentic skills development and for providing opportunities for them to prove, to share, and to expand the knowledge and the experiences that they have previously attained.

Teachers are one of the most important factors in the achievement of learning success within a school. Therefore, teachers should have very strategic function, role, and position.
The experts also emphasize the importance of teachers' role and position in the learning success of a school. Rowe [10] has emphasized the importance of teacher quality as the main determinant the students' learning experiences and the educational quality that will be achieved. Similarly, Lofland et al [8] states that teachers are one of the dominant factors that influence the students' learning process indirectly. In addition, Beeby in Beeby's Stages of Development mentions that teachers' education and preparation are considered as the main key of educational quality [11]. Due to these reasons, the efforts to improve the teachers' quality through the programs of teacher professionalism and development should be implemented.

\section{LIMITATIONS OF IMPLEMENTING LESSON STUDY}

Some of the limitations in implementing this lesson study can be described as follows:

- Lesson study implementation time which only lasts for two months contributes to the not optimal implementation of lesson study procedures. This is because at the beginning of the lesson study implementation, new students began the effective period of lectures.

- The time needed to plan the RPS and RPP (plan stage) is quite long due to the difficulty of gathering lecturers due to the density of lecturers' activities.

- The third problem is related to the class size which is quite large which consists of 40 students. The large number of students causes lectures to sometimes take place less effectively due to limited supervision and monitoring by the lecturer during lectures. Lecturers are often too overwhelmed in organizing ongoing discussions and observing student activeness, both in large and small groups, so there is often miscommunication and mismanagement in the classroom during lectures.

- In observation activities, observers still have difficulty making observations due to the lack of existing equipment. Students often forget to use the name take.

\section{CONCLUSION}

Based on the implementation of the learning that has been done, it can be concluded that:

1) The implementation of Lesson Study in the basic geology course has gone well, although there are several obstacles that need to be fixed in the next lesson, including some students who are less active in following lessons.

2) Lesson Study activities can encourage solidarity, cooperation and interaction between lecturers, between students and between lecturers and students.

3) An effective collaborative attitude in lesson study activities, especially at the plan stage, is very important in compiling and planning learning activities. This positive 
attitude is proven to help produce careful learning planning and will result in quality learning.

\section{REFERENCES}

[1] S. Mawaddah, "The Ability to Understand Mathematical Concepts of Junior High School Students in Learning Using Guided Discovery Modeling (Discovery Learning)," J. Math. Educ., vol. 4, no. 1, pp. 7685, 2016.

[2] K. Kholidah, "Analisis Pemahaman Konsep Matematika Siswa Kelas V Dalam Menyelesaikan Soal Di SD Negeri Gunturan Pandak," J. Pendidik. Ke-SD-an, vol. 4, pp. 428-431, 2018.

[3] B. Cerbin and W. Kopp, Lesson Study Guide [Online]. Retrieved from: http://www.uwlax.edu/sotl/lsp/guide, Accessed on October 252020 , 2011.

[4] V. Sanjaya, Competency-Based Learning and Curriculum Implementation. Jakarta: Kencana Perdana Media Group, 2011
[5] S. Sukirman, "Increasing Teacher Professionalism through Lesson Study," Pap. Present. Lesson Study Train. Interpret. Teach. Manag. MGMP MIPA SMP throughout Cent. Indones., 2006.

[6] K. Hendayana and S. Suryadi, Lesson study: Suatu strategi untuk meningkatkan keprofesionalan pendidik. Bandung: UPI Press, 2006.

[7] S. Masaaki, "Dialog dan kolaborasi di sekolah menengah pertama "praktik learning community," PELITA-JICA, Tokyo, 2012.

[8] L.H. Lofland, J. Snow and D.A. Lofland, Analyzing social settings: A guide to qualitative observation and analysis, 2006

[9] W. Chassels and C. Melville, "Collaborative, reflective, and iterative japanese lesson study in an initial teacher education program: benefits and challenges," Can. J. Educ. Can. L'éducation, vol. 32, no. 4, pp. 734 $763,2017$.

[10] K. Rowe, "The Importance of teacher quality as a key determinant of students' experiences and outcomes of schooling," Aust. Counc. Educ. Res., pp. 15-23, 2003.

[11] A. Barrett, R. Chawla-Duggan, J. Lowe, J. Nikel and E. Ukpo, "Review of the'International'Literature on the Concept of Quality in Education," Bristol, EdQual, pp. 1-9, 2006 